\title{
Life cycle sustainability assessment of geothermal heating and cooling system: UIC case study
}

\author{
Krishna R. Reddy*1, Sanjeeta N. Ghimire ${ }^{1}$, Emmanuelle Wemeyi ${ }^{1}$, Roya Zanjani ${ }^{1}$, Liang Zhao ${ }^{1}$ \\ ${ }^{1}$ Department of Civil and Materials Engineering, University of Illinois at Chicago, Chicago, IL60607, USA
}

\begin{abstract}
This study presents a sustainability assessment of geothermal heating and cooling system of three buildings at the University of Illinois at Chicago - Grant, Lincoln, and Douglas Halls based upon the triple bottom line sustainability framework and presents a comparison between geothermal and conventional heating and cooling systems. Life cycle assessment (LCA) was performed to evaluate and quantify the environmental impacts for both geothermal and conventional systems. Similarly, economic impacts were evaluated by making a comparison between direct and indirect costs of both systems. Indirect costs were calculated using Stepwise 2006 incorporated in monetized LCA and compared that cost with social cost of carbon. Social impacts were quantified using Social Sustainability Evaluation Matrix (SSEM) which covers four major dimensions of society: social-individual, socio-institutional, socio-economic, and socio-environmental. An overall sustainability index for geothermal system and conventional system was calculated by evaluating environmental, economic, and social impacts using Integrated Value Model for Sustainability Assessment (MIVES) methodology. The results show that the geothermal heating and cooling system is more sustainable and environmentally friendly than the conventional system.
\end{abstract}

\section{Introduction}

Thermal comfort has been a key aspect of a successful building design as it has a direct and strong influence on the occupant's productivity, health, as well as the overall efficiency of energy system in the building. With the increasing awareness of the thermal comfort, a largescale exploitation of fossil fuels has been taking place which has led to environmental concerns at a global scale [1]. Traditional energy sources for heating and cooling systems are limited and non-renewable, such as natural gas, propane, coal, etc. Recent studies have shown that heating and cooling account for about $48 \%$ of the energy use in a typical U.S. home, making it as one of the largest energy expenses.

The U.S. Environmental Protection Agency (USEPA) has concluded that a well-designed geothermal heat pump system produces less environmental impacts than any other alternative energy systems and it is the most efficient technology with low greenhouse gas (GHG) emissions and global warming effects [2]. According to USEPA, geothermal energy is a renewable source of thermal energy generated and stored few feet under the surface of the earth. The ground temperature within this system remains 45 to 75 degrees Fahrenheit which can differ depending on the latitude and climate of specific location. As energy is not burned to produce heating or cooling, there is negligible carbon emissions and significant amount of energy can be saved at the same time. The geothermal system can reduce annual operational emissions by up to $88 \%$ in comparison to various methods of traditional HVAC (Heating, Ventilation, and Air Conditioning) systems. Although it may have higher installation cost in the beginning, it is proven to have a lower operation and maintenance cost in future with minimal environmental cost apart from all other technologies [3].

Sustainability is mostly expressed in terms of environmental benefit and cost efficiency, and the social aspects are generally overlooked. For a system to be sustainable, it should have net environmental, economic, and social benefits. In this study, a sustainability assessment of geothermal system and conventional system used in three different buildings of University of Illinois at Chicago (UIC)'s east campus - Grant Hall, Lincoln Hall, and Douglas Hall is presented. The University's energy record shows that a constant indoor temperature of 73 degrees Fahrenheit runs throughout the year and 50\% energy is saved using geothermal system compared to previously installed conventional system. The main objective of this study is to present a comparative analysis of the sustainability of geothermal heating and cooling system with the conventional heating and cooling system.

\section{Project Background}

Conventional HVAC system typically includes a direct electric heating and cooling or burning fossil fuels to convert to heat. If the geothermal energy is used as an

\footnotetext{
* Corresponding author: kreddy@uic.edu
} 
alternative to the conventional system, the energy bills can be reduced by half [4]. Although geothermal system is highly efficient and a reliable alternative, it has remained as an underutilized system due to the large cost of installation, poorly understood technology, and lack of skilled manpower. It is worth noting that because of high cost of installation in geothermal system, conventional system can be preferred by majority of the households. But, the benefits of geothermal system and its long payback usefulness is undeniable [ 5].

Sustainability assessment of geothermal and conventional systems performed in this study provides a quantitative basis for comparison between the two systems and enhance the overall understanding of their environmental, economic, and social impacts. The main motivation to choose UIC's infrastructure was to analyze the real case scenario and to perceive that sustainability is a global requirement which has been initiated by the institutions like UIC. Lincoln and Douglas Halls are both the LEED (Leadership in Energy and Environmental Design) certified buildings and they highly promote sustainable building materials and landscaping. So, the proposed study can be useful for promoting the legacy set by UIC in terms of energy saving and can be influencing for the application of these concepts for the future researchers and stakeholders.

The geothermal system installed at UIC contains three major components: the loop, heat pump, and the distribution system. The series of pipes called "loop" carries a fluid to connect the geothermal system's heat pump to the earth. A vertical underground looping system has been applied, as UIC is rather a larger institution and the land area is quite restrictive. As the heat supplied from the vertical loops might not be enough for direct use into the building, the heat pumps are used to supply adequate heating to the buildings. In the heating mode, as the fluid travels to the heat pump (which has refrigerant), the heat is transferred to the refrigerant and it creates a compressed vapor to increase temperature and pressure. The distribution system collects the heat and distributes throughout the building. Similarly, in the cooling mode, the direction of the fluid flow is reversed, and the refrigerant absorbs the heat from building, and it transfers the heat to the fluid which is finally released to the ground.

The three buildings of UIC's east campus were considered in this study. Grant Hall has an area of 15,000 square-feet primarily used for offices and classrooms, Lincoln Hall has an area of 25,000 squarefeet also used for offices and classrooms, and Douglas Hall has an area of 25,000 square-feet used for the business school. These buildings use a vertical closedloop geothermal system with heat pumps, and heat exchangers.

The vertical loop of the geothermal system is located below the field just the east side of University Hall that hosts a vertical labyrinth of pipes that heats and cools the air in the proposed buildings. There are total of 64 boreholes of 4-inch diameter each which are drilled to a depth of 550 feet each. The spacing between each borehole is 20 feet apart. High density polyethylene (HDPE) pipes sizing $1 \frac{1 / 4}{4}$ of 66,520 feet is used for the branches connecting from boreholes to the main vault. Similarly, 25,000 feet of 4" HDPE pipes are used for connecting the buildings to the main vault. Propylene glycol is used as the anti-freezing liquid in the vertical loops of HDPE pipes. High solids bentonite is used for the backfilling and grouting in the boreholes. There are altogether 92 heat pumps used in the overall system of three buildings where Grant Hall consists of 20, Lincoln Hall consists of 30, and Douglas Hall consists of 42 heat pumps. These heat pumps are attached to the earth connection by the loop by which each area of the buildings can be controlled individually.

\section{Methodology}

\subsection{Environmental Sustainability}

Environmental sustainability was evaluated by using the life cycle assessment (LCA) methodology. LCA is a cradle to grave approach which considers environmental impacts from all the life cycle stages (from material acquisition to waste disposal) of an activity or a process/ system. TRACI 2.1 V1.01 / US 2008 and software inbuilt inventory of materials and transportation were used for the input data. Different life cycle stages considered in the LCA approach are raw materials or resources, material processing, product manufacturing, distribution, use, and end of life $[6,7,8]$.

The weight of materials for each system component is evaluated by using the total units of each material for three buildings. The calculation is based on the standard catalogue of materials and manufacturer's websites. Similarly, the total transportation distance is based on the distance between the manufacturer's location and the UIC. For example, the mileage for heat pump for three buildings are shown to be different as these buildings use different heat pumps and they come from different companies. The life cycle inventories for raw material like $\mathrm{kg}$ amount and transportation in tones$\mathrm{km}$ (based on the distance travelled by the weight of the materials) are summarized in Tables 1 and 2.

\subsection{Economic Sustainability}

The economic sustainability assessment was performed by evaluating direct and indirect costs. The direct cost was calculated based upon the raw materials required for the systems, transportation, and labor for drilling and installation. The indirect cost was calculated using Stepwise 2006 LCA and this was further compared with Social Carbon Cost as presented by USEPA. The operational period of the heating and cooling systems was set for 20 years of life span for comparative purposes.

The direct cost for geothermal heating and cooling system was calculated by considering the raw materials such as heat pump, ground loop, anti-freezing liquid, backfill and grout, circulating pump, heat exchanger, cement, electricity to operate heat pumps, and gasoline for drilling and installation. Similarly, for the conventional heating and cooling system, the raw 
materials were divided into natural gas furnace, total electricity required for the three buildings, air conditioner, and ductwork. The transportation cost of geothermal heating and cooling system was calculated in terms of different components that need to be transported from the manufacturing location to the site. The labor cost was evaluated by dividing the labor into several categories including company personnel, directional drillers, mud engineer, solid dude, etc.

Table 1. Raw Material Inventories for Geothermal and Conventional Systems

\begin{tabular}{|c|c|c|c|}
\hline $\begin{array}{c}\text { Category } \\
\text { A }\end{array}$ & $\begin{array}{c}\text { System } \\
\text { Component }\end{array}$ & $\begin{array}{l}\text { Material } \\
\text { Geothermal System }\end{array}$ & Weight (kg) \\
\hline 1 & $\begin{array}{l}\text { Heat Pumps and } \\
\text { Installation }\end{array}$ & For 3 Buildings & 39100 \\
\hline \multirow{2}{*}{2} & \multirow{2}{*}{$\begin{array}{l}\text { Ground Loop } \\
\text { Pipes }\end{array}$} & 1 1/4" HDPE Pipe & 11164 \\
\hline & & 4" HDPE Pipe & 31184 \\
\hline 3 & $\begin{array}{l}\text { Anti-freezing } \\
\text { Liquid }\end{array}$ & $\begin{array}{l}\text { Propylene Glycol } \\
\text { (1 } 1 / 4 " \text { " \& 4" HDPE) }\end{array}$ & 37450 \\
\hline 4 & $\begin{array}{l}\text { Backfill and } \\
\text { Grout }\end{array}$ & $\begin{array}{l}\text { High Solids } \\
\text { Bentonite }\end{array}$ & 1475 \\
\hline 5 & $\begin{array}{l}\text { Circulating } \\
\text { Pump }\end{array}$ & Cast Iron & 109500 \\
\hline 6 & Heat Exchanger & Heat Exchanger & 190 \\
\hline 7 & Cement & OPC Cement & 1925 \\
\hline 8 & Electricity & $\begin{array}{c}\text { To Operate Heat } \\
\text { Pumps }\end{array}$ & $3020 \mathrm{kwh}$ \\
\hline 9 & $\begin{array}{l}\text { Gasoline for } \\
\text { Drilling and } \\
\text { Installation }\end{array}$ & $1500 \mathrm{gal} /$ day & 170550 \\
\hline \multirow[t]{2}{*}{$\begin{array}{c}\text { Category } \\
\text { B }\end{array}$} & $\begin{array}{c}\text { System } \\
\text { Component }\end{array}$ & Material & Weight (kg) \\
\hline & \multicolumn{3}{|c|}{ Conventional System } \\
\hline \multirow{3}{*}{1} & \multirow{3}{*}{$\begin{array}{l}\text { Natural Gas } \\
\text { Furnace } \\
\text { (For } 3 \\
\text { Buildings) }\end{array}$} & $\begin{array}{c}\text { Galvanized Steel } \\
(55 \%)\end{array}$ & 512400 \\
\hline & & Aluminum $(25 \%)$ & 80109 \\
\hline & & Copper $(20 \%)$ & 212674 \\
\hline 2 & Total Electricity & For 3 Buildings & $107820 \mathrm{kWh}$ \\
\hline \multirow{4}{*}{3} & \multirow{4}{*}{$\begin{array}{c}\text { Air Conditioner } \\
\text { (For } 3 \\
\text { buildings) }\end{array}$} & Steel $(45 \%)$ & 411226 \\
\hline & & $\begin{array}{c}\text { Galvanized Steel } \\
(35 \%)\end{array}$ & 326073 \\
\hline & & Copper $(10 \%)$ & 106337 \\
\hline & & Aluminum $(10 \%)$ & 32043 \\
\hline 4 & Ductwork & Galvanized Steel & 10126 \\
\hline
\end{tabular}

Similarly, the indirect cost of the project was analyzed using the Stepwise 2006 built in LCA SimaPro software. Stepwise 2006 was used for the monetary evaluation of environmental impacts in LCA which carries all the impacts forward to a single monetary unit.

The social cost of carbon signifies the long-term damage caused by one ton of carbon dioxide $\left(\mathrm{CO}_{2}\right)$ emissions each year. The social cost of carbon (20152020) was obtained from the USEPA website and a 3\% average rate for 2020 was $\$ 42$ per metric ton of global warming fossil [9]. So, the value of global warming fossil with $\mathrm{kg}$ carbon equivalent $(\mathrm{kg} \mathrm{CO}$-eq) obtained from geothermal and conventional systems were multiplied by $\$ 42$ to predict the social carbon cost in the year 2020. Similarly, the US dollars 2002 value of the global warming fossil was taken from Stepwise calculation and multiplied by $43.05 \%$ inflation rate to convert into the present dollar amount and calculated the total indirect cost based on Stepwise data.

Table 2. Transportation Inventories for Geothermal and Conventional Systems

\begin{tabular}{|c|c|c|c|c|c|c|}
\hline & $\begin{array}{l}\text { System } \\
\text { Materials }\end{array}$ & $\begin{array}{l}\text { Dist. } \\
\text { (mile) }\end{array}$ & $\begin{array}{c}\text { Cost } / \mathbf{m} \\
\text { ile } \\
(\$ 1.69)\end{array}$ & $\begin{array}{l}\text { Dist. } \\
\text { (km) }\end{array}$ & $\begin{array}{l}\text { Wt. } \\
\text { (Ton) }\end{array}$ & $\begin{array}{c}\text { Total } \\
\text { Tons-km }\end{array}$ \\
\hline $\mathbf{A}$ & \multicolumn{6}{|c|}{ Geothermal System } \\
\hline 1 & \multicolumn{6}{|c|}{ Heat Pump } \\
\hline & $\begin{array}{l}\text { Lincoln } \\
\text { Hall }\end{array}$ & 1600 & 2704 & \multirow{3}{*}{\multicolumn{3}{|c|}{$\begin{array}{l}\text { *Distance travelled for } 3 \text { halls } \\
\text { are different though they are } \\
\text { in the same complex, because } \\
\text { of the different manufacturing } \\
\text { location. }\end{array}$}} \\
\hline & $\begin{array}{c}\text { Douglas } \\
\text { Hall }\end{array}$ & 1600 & 2704 & & & \\
\hline & Grant Hall & 1956 & 3305.64 & & & \\
\hline & \multicolumn{3}{|c|}{ Total Heat Pump } & 8249.6 & 39.1 & 322559 \\
\hline \multirow[t]{2}{*}{2} & $\begin{array}{l}\text { Ground } \\
\text { Loop } \\
\text { Piping }\end{array}$ & 92 & 155.48 & 147.2 & & \\
\hline & $\begin{array}{l}\text { Total } \\
\text { HDPE }\end{array}$ & & & 42348.47 & 42.35 & 6233 \\
\hline \multirow[t]{2}{*}{3} & \multicolumn{2}{|c|}{ Glycol Solution } & & & & \\
\hline & $\begin{array}{l}\text { Propylene } \\
\text { Glycol }\end{array}$ & 170 & 287.3 & 272 & 37.45 & 10186 \\
\hline \multirow[t]{2}{*}{4} & \multicolumn{2}{|c|}{ Backfill and Grout } & & & & \\
\hline & $\begin{array}{c}\text { High Solids } \\
\text { Bentonite }\end{array}$ & 2260 & 3819.4 & 3616 & 1.48 & 5335 \\
\hline \multirow[t]{5}{*}{5} & \multicolumn{2}{|c|}{ Circulating Pump } & & & & \\
\hline & $\begin{array}{c}\text { Lincoln } \\
\text { Hall }\end{array}$ & 28 & 47.32 & & & \\
\hline & $\begin{array}{c}\text { Douglas } \\
\text { Hall }\end{array}$ & 28 & 47.32 & & & \\
\hline & Grant Hall & 28 & 47.32 & & & \\
\hline & \multicolumn{3}{|c|}{ Total Circulating Pump } & 134.4 & 109.5 & 14716 \\
\hline \multirow[t]{5}{*}{6} & \multicolumn{2}{|c|}{ Heat Exchanger } & & & & \\
\hline & $\begin{array}{c}\text { Lincoln } \\
\text { Hall }\end{array}$ & 28 & 47.32 & & & \\
\hline & $\begin{array}{c}\text { Douglas } \\
\text { Hall }\end{array}$ & 28 & 47.32 & & & \\
\hline & Grant Hall & 28 & 47.32 & & & \\
\hline & \multicolumn{3}{|c|}{ Total Heat Exchanger } & 134.4 & 0.19 & 25 \\
\hline 7 & Cement & 6.6 & 11.15 & 10.56 & 1.93 & 20 \\
\hline B & \multicolumn{6}{|c|}{ Conventional System } \\
\hline 1 & $\begin{array}{c}\text { Natural Gas } \\
\text { Furnace }\end{array}$ & 258 & 436.02 & 412.8 & 805.18 & 332380 \\
\hline 2 & $\begin{array}{c}\text { Air } \\
\text { Conditioner }\end{array}$ & 258 & 436.02 & 412.8 & 875.68 & 361480 \\
\hline 3 & Ductwork & 29.4 & 49.69 & 47.04 & 10.13 & 476 \\
\hline
\end{tabular}

\subsection{Social Sustainability}

The social sustainability attempts to quantify the social impacts that the systems would have on the community or the society around the site. In this study, Social Sustainability Evaluation Matrix (SSEM) was used to 
compare the social sustainability of the two systems [10]. The matrix covers four different dimensions of social interaction with the building and surrounding environment: Social-Individual, Socio-Institutional, Socio-Economic, and Socio-Environmental. Each dimension consists of key theme areas which need to be filled out by the users with certain scaling in order to get the results from the matrix (Table 3 ). In this study, a scale of -2 to $+2(-2$ being the worst and +2 being the best) for each key theme area that best describes the impacts of associated system activity at four dimensions were chosen. SSEM results were obtained by conducting an online survey among the respondents having knowledge in the area of this project.

Table 3. Social Sustainability Dimensions and Key Theme Areas Considered in this Study

\begin{tabular}{|c|c|}
\hline Dimension & Key Theme Areas/Indicators \\
\hline \multirow{5}{*}{$\begin{array}{l}\text { Social- } \\
\text { Individual }\end{array}$} & $\begin{array}{l}\text { Effect of system on quality of life during } \\
\text { the construction stages }\end{array}$ \\
\hline & $\begin{array}{l}\text { Effect of system on quality of life during } \\
\text { the operation and management stages }\end{array}$ \\
\hline & $\begin{array}{l}\text { Effect of system on overall individual } \\
\text { health }\end{array}$ \\
\hline & $\begin{array}{l}\text { Effect of noise to the people living inside } \\
\text { house }\end{array}$ \\
\hline & Safety of the residents and the houses \\
\hline \multirow{5}{*}{$\begin{array}{c}\text { Socio- } \\
\text { Institutional }\end{array}$} & Future land use for the community \\
\hline & $\begin{array}{l}\text { Enhancement and participation of } \\
\text { research institutes for sustainable projects }\end{array}$ \\
\hline & $\begin{array}{l}\text { Potential of attracting newcomers to the } \\
\text { community }\end{array}$ \\
\hline & $\begin{array}{l}\text { Design and installation flexibility in the } \\
\text { community }\end{array}$ \\
\hline & $\begin{array}{l}\text { Incorporation of green and sustainable } \\
\text { infrastructure into construction and } \\
\text { management }\end{array}$ \\
\hline \multirow{5}{*}{$\begin{array}{l}\text { Socio- } \\
\text { Economic }\end{array}$} & $\begin{array}{l}\text { Employment opportunities during } \\
\text { construction and maintenance }\end{array}$ \\
\hline & $\begin{array}{l}\text { Relative degree of increased revenue for } \\
\text { the government }\end{array}$ \\
\hline & $\begin{array}{l}\text { Long term cost of operation and } \\
\text { management }\end{array}$ \\
\hline & Life cycle and reliability of the system \\
\hline & Initial investment of the system \\
\hline \multirow{5}{*}{$\begin{array}{c}\text { Socio- } \\
\text { Environmental }\end{array}$} & $\begin{array}{l}\text { Degree proposed system will affect other } \\
\text { media (i.e., emissions/air pollution } \\
\text { resulting from soil or groundwater) }\end{array}$ \\
\hline & $\begin{array}{l}\text { Degree of noise pollution from heating } \\
\text { and cooling system to the surrounding } \\
\text { neighborhoods }\end{array}$ \\
\hline & Eco-friendly operation and management \\
\hline & $\begin{array}{l}\text { The impact of greenhouse gas emission on } \\
\text { global warming }\end{array}$ \\
\hline & Energy consumption \\
\hline
\end{tabular}

\subsection{Integrated Assessment}

To quantify the impact categories evaluated in various units into a common unit is challenging. Hence, the Integrated Value Model for Sustainability Assessment (MIVES model) was adopted for the integrated assessment which deals with the standardization of units to express different variables or indicators involved for sustainability. It normalizes the numeric values in all impact categories into a non-dimensional unit based upon the functional values chosen for the indicators. At first, the tendencies of value function were chosen on a scale of 0 to 1 , where 0 reflects the minimum satisfaction $\left(\mathrm{S}_{\min }\right)$ and 1 reflects the maximum satisfaction $\left(\mathrm{S}_{\max }\right)$. The value function is of four types: a) concave, b) convex, c) linear, and d) s-shaped (see Fig. 1).

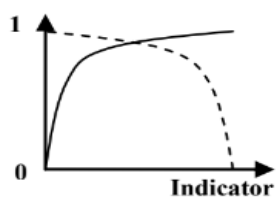

(a)

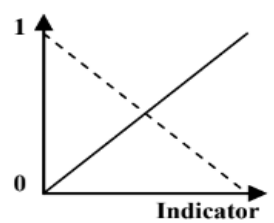

(c)

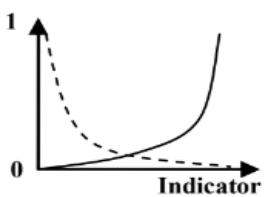

(b)

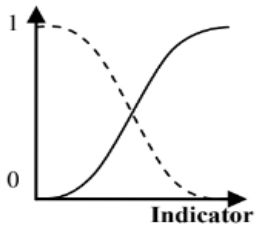

(d)
Fig. 1. Types of Value Function Curves

The shape of the curve $(\mathrm{P})$, Value indicator $\left(\mathrm{V}_{\text {ind }}\right), \mathrm{B}$ (factor that allows function to remain between 0 to 1 ), etc. are chosen accordingly [11] where,

$$
\begin{aligned}
& V_{\text {ind }}=B *\left[1-e^{-K *\left(\frac{\left|X-S_{\text {min }}\right|}{C}\right)^{P}}\right] \\
& B=\frac{1}{\left[1-e^{\left.-\mathbb{W} \cdot\left(\frac{S_{\text {maex }}-S_{\text {man }} \mid}{C}\right)^{P}\right]}\right.}
\end{aligned}
$$

In this study, the value function for environmental indicators was chosen to be decreasing concave as all the impact categories are decreasing the sustainability. Similarly, the value function for economic and social were considered to be decreasing convex and linear sshape respectively. In the economic analysis, as the direct cost of geothermal system was higher than that of indirect cost, two other tests with concave and s-shape functions were also carried out to check the consistency of the result. The environmental, economic, and social indicators were weighted equally $(33.33 \%$ each). Following the MIVES methodology and the framework explained by Trentin et al. [12], sustainability index was calculated for both geothermal and conventional systems. 


\section{Results and Discussion}

\subsection{Environmental Sustainability}

Fig. 2 shows the environmental impacts associated with geothermal and conventional system in terms of 10 impact categories including ozone depletion and global warming. Overall result shows that the geothermal system has less impact to the environment than that of conventional system. Because the geothermal system does not need burning or combustion of fossil fuels for heat production, it generates negligible greenhouse gas emissions than a conventional furnace. So, it can be concluded that the geothermal system is environmentally sustainable than conventional system.

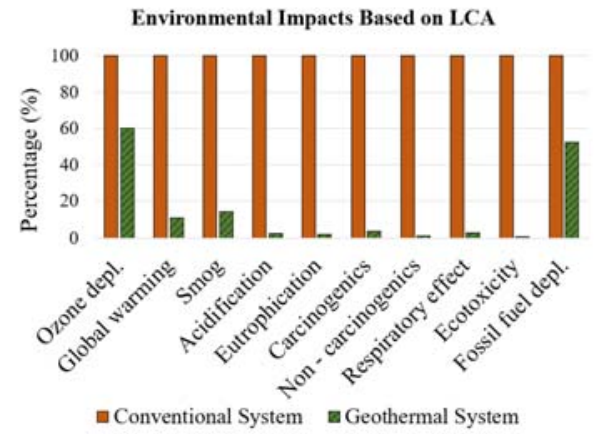

Fig. 2. Comparison of Relative Environmental Impacts Based on Life Cycle Assessment (LCA)

\subsection{Economic Sustainability}

The direct materials cost of geothermal heating and cooling system and conventional system are estimated to be $\$ 2,084,836$ and $\$ 1,029,462$. The total cost of geothermal heating and cooling system in terms of transportation is $\$ 13,270$. Direct transportation cost of conventional heating and cooling system costs $\$ 921$ which is comparatively lower than geothermal systems as most of the components of conventional system are transported from manufacturing companies in Chicago and nearby cities. The total cost of labor for geothermal system is estimated to be $\$ 314,220$ and that for conventional system is $\$ 135,096$ which includes director, finance assistant senior, chief operation engineer, assistant chief operation engineer, etc. The results demonstrated that the overall cost for geothermal heating and cooling system was more than the conventional heating and cooling system (Table 4).

Table 4. Overall Cost of Geothermal and Conventional Systems

\begin{tabular}{|c|c|c|}
\hline Categories & Geothermal & Conventional \\
\hline Raw Materials Cost & $\$ 2,084,836$ & $\$ 1,029,462$ \\
\hline Transportation Cost & $\$ 13,270$ & $\$ 921$ \\
\hline Labor Cost & $\$ 314,220$ & $\$ 135,096$ \\
\hline Total Direct Cost & $\mathbf{\$ 2 , 4 1 2 , 3 2 7}$ & $\mathbf{\$ 1 , 1 6 5 , 4 8 0}$ \\
\hline
\end{tabular}

Fig. 3 illustrates the monetized environmental costs based on Stepwise evaluation for all the impact categories from LCA. The results show that the geothermal system is economically sustainable than conventional system. But, one of the impact categories, eutrophication, showed negative value which means it has a beneficial effect on the environment. This is because of the galvanized steel that is used in natural gas furnace and air conditioner in conventional system. The ammonium ion substance in the galvanized steel has negative value which is contributing to the sustainability.

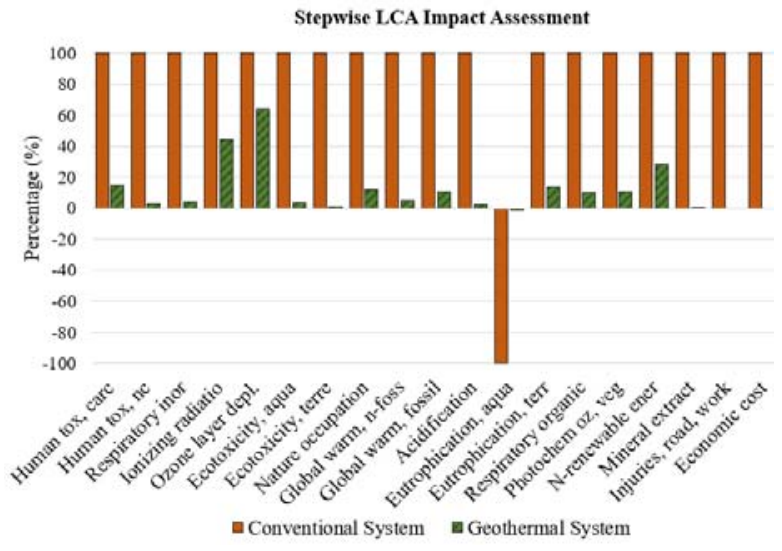

Fig. 3. Comparison of Stepwise LCA Impact Assessment

Further, the monetized global warming costs from Stepwise and the USEPA Social Carbon Cost are compared in Table 5. It shows that the geothermal system is economically sustainable if the indirect costs were accounted. The indirect cost of conventional system is about 2.7 times higher than that of geothermal system, which refers to the unsustainability of conventional system because of higher carbon cost and consequences associated with it.

Table 5. Comparison of monetized greenhouse gas costs as per Stepwise and USEPA Social Carbon Cost

\begin{tabular}{|c|c|c|c|c|}
\hline Method & $\begin{array}{c}\text { Impact } \\
\text { categ. }\end{array}$ & Unit & Geothermal & Conventional \\
\hline $\begin{array}{c}\text { Stepwise } \\
2006\end{array}$ & $\begin{array}{l}\text { Global } \\
\text { Warm. } \\
\text { Fossil }\end{array}$ & $\begin{array}{l}\mathrm{kg} \\
\mathrm{CO} 2\end{array}$ & 619,889 & $5,739,437$ \\
\hline $\begin{array}{c}\text { USEPA } \\
\text { SCC } \\
\text { Stepwise } \\
\text { kg CO2 eq }\end{array}$ & $\begin{array}{c}\text { US } \\
\text { EPA } \\
\$ 42 / \mathrm{m} . \\
\text { ton }\end{array}$ & $\begin{array}{l}\text { USD } \\
2020\end{array}$ & $\$ 26,035$ & $\$ 241,056$ \\
\hline $\begin{array}{l}\text { Stepwise \$ } \\
2002 \text { LCA }\end{array}$ & $\begin{array}{l}\text { Global } \\
\text { Warm. } \\
\text { Fossil }\end{array}$ & $\begin{array}{l}\text { USD } \\
2002\end{array}$ & $\$ 49,700$ & $\$ 460,000$ \\
\hline $\begin{array}{c}\text { Stepwise \$ } \\
2020 \\
\text { Convert }\end{array}$ & $\begin{array}{l}\text { Global } \\
\text { Warm. } \\
\text { Fossil } \\
\end{array}$ & $\begin{array}{l}\text { USD } \\
2020 \\
43 \% \\
\end{array}$ & $\$ 71,095$ & $\$ 658,030$ \\
\hline
\end{tabular}

\subsection{Social Sustainability}

The results of SSEM analysis are presented in Fig. 4 which is based on the 18 responses obtained from the online survey. Among the four categories, geothermal heating and cooling system received the highest score 
making it much more acceptable socially and sustainable compared to conventional system. Based on the survey results, the geothermal heating and cooling system was suggested as an effective means to reduce the energy consumption, reduce greenhouse gas emissions, and reduce homeowners' heating and cooling costs.

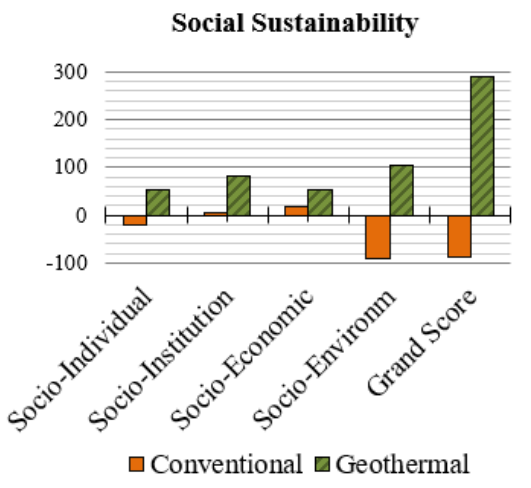

Fig. 4. SSEM Results from Survey

\subsection{Integrated Assessment}

Fig. 5 shows the sustainability index values obtained for each impact categories as well as the integrated sustainability index value. The sustainability index of geothermal system was higher than that of the conventional system when the three pillars of sustainability were given equal weightages. The sustainability indices of the geothermal system were also higher in other two weighting scenarios (environmental $20 \%$, economic 20\%, and social $60 \%$ ) and (environmental $25 \%$, economic $50 \%$, and social $25 \%$ ).

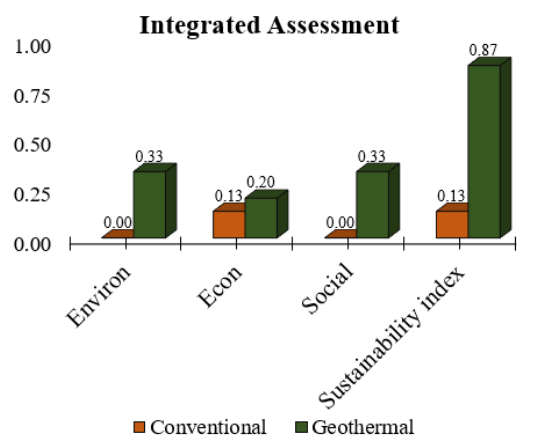

Fig. 5. Comparison of Sustainability Index Values Based on Integrated Assessment from MIVES Model

\section{Conclusions}

The primary goal of this study was to compare the sustainability of geothermal heating and cooling system with the conventional heating and cooling system using a triple bottom line framework which accounts for the three main pillars of sustainability: environmental, economic, and social. Based on the application of life cycle sustainability assessment framework for the UIC geothermal system, the following conclusions can be drawn from the study:

a. From the environmental, economic, and social point of view, geothermal system is more sustainable than conventional system.

b. Direct cost of geothermal system is higher than conventional system. Initially, geothermal system seems to be unsustainable based on the cost of extensive installation and drilling. However, the indirect cost of conventional system is much higher than that of the geothermal system.

c. From the MIVES model integrated assessment, it shows that geothermal system is more sustainable in all triple bottom line categories.

\section{References}

1. M. Zheng, R. Fang, Z. Yu., Life cycle assessment of residential heating systems: A comparison of distributed and centralized systems, Ener. Proc., 104, 287-292 (2016)

2. USEPA, Renewable Heating and Cooling, Retrieved from https://bit.ly/2sphKNJ (December 19, 2016)

3. A.K. Hunter, Comparative Life Cycle Assessment: Ground Source Heat Pump System Versus Gas Furnace and Air Conditioner System (2017)

4. M. Soltani, F.M. Kashkooli, A.R. Dehghani-Sanij, A.R. Kazemi, N. Bordbar, M.J. Farshchi, M.B. Dusseault, A comprehensive study of geothermal heating and cooling systems, Sust. Cities and Soc., 44,793-818 (2019)

5. A.M. Omer, Ground-source heat pumps systems and applications, Ren. and Sust. Ener. Rev., 12(2), 344-371 (2008)

6. K.R. Reddy, C. Cameselle, J.A. Adams, Sustainable Engineering: Drivers, Metrics, Tools, and Applications, John Wiley and Sons (2019)

7. Pré SimaPro 8.5 LCA software, (2018)

8. J.C. Bare, The tool for the reduction and assessment of chemical and other environmental impacts, J. Ind. Eco., 6(3-4): 49-78 (2002)

9. USEPA, Climate Change, Retrieved from https://bit.ly/2PHDCLR (January 29, 2018)

10. K.R. Reddy, B.Y. Sadasivam, J.A. Adams, Social sustainability evaluation matrix (SSEM) to quantify social aspects of sustainable remediation, Proc. Creating Inf. Sust. World, ASCE, pp. 831-841 (2014)

11. B. Alarcon, A. Aguado, R. Manga, A. Josa, $A$ value function for assessing sustainability: application to industrial buildings, Sust., 3(1), 3550 (2011)

12. A.W. da S Trentin, K.R. Reddy, G. Kumar, J.K. Chetri, A. Thomé, Quantitative assessment of life cycle sustainability (QUALICS): Framework and its application to assess electrokinetic remediation, Chemosphere., 230, 92-106 (2019) 